\title{
ANALISIS NILAI TAMBAH NATRIUM LAURAT DAN KALIUM PALMITAT SEBAGAI BAHAN BAKU FOAMING AGENT PEMADAM KEBAKARAN
}

\section{ANALYSIS VALUE ADDED OF SODIUM LAURIC AND POTASSIUM PALMITATE AS RAW MATERIALS FOAMING AGENT PEAT FIRE SUPPRESSION}

\author{
Purwo Subekti $^{1 *}$, Erliza Hambali ${ }^{2)}$, Ani Suryani'), Prayoga Suryadarma ${ }^{2)}$, Bambang Hero Saharjo ${ }^{3)}$ \\ ${ }^{1)}$ Program Studi Teknik Mesin Fakultas Teknik, Universitas Pasir Pengaraian, Rokan Hulu, Riau \\ JL.Tuanuku Tambusai, Rambah Hilir,Kabupaten Rokan Hulu, Riau, Indonesia \\ E-mail: purwos73@gmail.com \\ ${ }^{2}$ Departemen Teknologi Industri Pertanian, Fakultas Teknologi Pertanian, Institut Pertanian Bogor \\ ${ }^{3)}$ Departemen Silvikultur, Fakultas Kehutanan, Institut Pertanian Bogor \\ Makalah: Diterima 12 November 2020; Diperbaiki 15 Desember 2020; Disetujui 20 Desember 2020
}

\section{ABSTRACT}

The calculation of the added value of using a foaming agent based on sodium lauric and potassium palmitate for palm oil as a peatland fire suppression needs to be studied. This was to determine prospects for further development because it is predicted that peatland fires will continue to recur every year during the dry season. The Hayami method used to analyze the added value of sodium lauric and potassium palmitate as the primary raw materials for foaming agents. The results showed that the production of foaming agents for peatland firefighting applications made from sodium laurate and potassium palmitate of palm oil provided added value with positive criteria, i.e. the ratio of value-added criteria was $80.87 \%$ (>0). In addition to that, the business also provided highprofit categories because the added value category ratio was $80.87 \%$ (> 40\%). From the analysis of remuneration, it was produced that the foaming agent production business was a capital-intensive since the contribution of the labour income value was $0.89 \%$, other expenses contributed $3.73 \%$ and the profit from the entrepreneur as the owner capital of $95.37 \%$ which was the largest contribution in providing profit margins. However, the development of a foaming agent production business based on palm oil fatty acids will add new jobs and create new economic impacts in the area of the business locations as well as to increase the amount of palm oil derivative products.

Keywords: added value, foaming agent, sodium lauric, potassium palmitate, palm oil

\section{ABSTRAK}

Perhitungan nilai tambah dari penggunaan foaming agent berbasis natrium laurat dan kalium palmitat minyak sawit sebagai pemadam kebakaran lahan gambut perlu dilakukan kajian. Hal tersebut dilakukan untuk mengetahui prospek ke depan untuk pengembangan lebih lanjut karena diprediksi kebakaran lahan gambut akan terus berulang setiap tahun pada musim kemarau. Metode yang digunakan untuk menganalisis nilai tambah dari natrium laurat dan kalium palmitat sebagai bahan baku utama foaming agent adalah metode Hayami. Hasil analisis menunjukan bahwa nilai tambah produksi foaming agent untuk aplikasi pemadam kebakaran lahan gambut berbahan baku natrium laurat dan kalium palmitat minyak sawit menunjukan kriteria positif (>0), yaitu sebesar 80,87\%. Selain itu, usaha tersebut juga memberikan keuntungan dengan kategori tinggi karena rasio kategori nilai tambah sebesar $80,87 \%$ (> 40\%). Analisis balas jasa menyajikan bahwa usaha produksi foaming agent merupakan usaha padat modal karena kontribusi dari nilai pendapatan tenaga kerja sebesar 0,89\%, sumbangan biaya lain sebesar 3,73\%, dan keuntungan dari pengusaha selaku pemilik modal sebesar 95,37\% yang merupakan kontribusi terbesar dalam memberikan margin keuntungan. Namun demikian, dengan adanya pengembangan usaha produksi foaming agent akan menambah lapangan kerja baru dan menciptakan dampak ekonomi baru di daerah lokasi usaha serta peluang untuk meningkatkan jumlah produk turunan dari minyak sawit.

Kata kunci: nilai tambah, foaming agent, natrium laurat, kalium palmitat, minyak sawit

\section{PENDAHULUAN}

Asam laurat dan palmitat merupakan asam lemak minyak sawit yang merupakan salah satu komoditas unggulan Indonesia, yang mampu menopang kegiatan industri dan ekonomi. Tingginya kandungan asam lemak pada minyak sawit, menjadikan asam lemak banyak dimanfaatkan sebagai bahan baku pada berbagai jenis produk di antaranya adalah untuk kesehatan, makanan dan penanggulangan kebakaran. Penggunaan sebagian asam lemak minyak sawit sebagai salah satu bahan pemadam kebakaran, merupakan usaha dalam rangka untuk mengganti penggunaan bahan pemadam kebakaran yang sulit terdegradasi ke lingkungan (Mizuki et al., 2007).

Pengembangan produk turunan dari asam lemak terus berkembang dalam rangka untuk meningkatkan jumlah produk turunan yang terbuat dari minyak sawit, 
di antaranya sebagai bahan baku foaming agent untuk aplikasi pemadam kebakaran pada lahan gambut. Peningkatan jumlah produk dari bahan baku yang bersumber dari asam lemak minyak sawit, diharapkan memberikan kontribusi dalam meningkatkan jumlah penggunaan minyak sawit selain untuk bahan baku pangan dan stabilitas harga minyak sawit. Selain itu, pengembangan produk foaming agent diharapkan memberikan kontribusi di daerah yang sering terjadi kebakaran lahan gambut, dalam rangka mempercepat proses pemadaman dan mengurangi dampak kerusakan lingkungan akibat asap dari kebakaran lahan gambut (Subekti et al., 2017).

Pemanfaatan asam lemak minyak sawit sebagai bahan baku untuk pemadam kebakaran karena efek pembusaan yang baik pada asam laurat dan palmitat. Pengembangan asam lemak minyak sawit untuk pemadam kebakaran sudah dilakukan oleh beberapa peneliti di antaranya adalah Mizuki et al. (2007), JICA (2016), Rivai et al. (2017) dan Subekti et al. (2020). Hasil penelitian peneliti tersebut antara lain adalah bahwa busa dari air yang dicampur foaming agent berbahan dasar asam lemak minyak sawit mampu memadamkan kebakaran lahan gambut dengan baik, dengan durasi waktu padam lebih cepat di banding menggunakan air tanpa penambahan foaming agent. Selain itu, produk tersebut memiliki kemampuan menurunkan tegangan permukaan air yang baik sehingga mampu menghemat penggunaan air.

Perbaikan kinerja air dalam memadamkan kebakaran pada lahan gambut setelah penambahan foaming agent, sehingga memungkinkan dilakukan pengembangan produksi foaming agent menggunakan bahan baku asam laurat dan palmitat dari minyak sawit. Namun demikian perlu dilakukan kajian tentang nilai tambah terlebih dahulu, dari penggunaan asam laurat dan palmitat sebagai bahan baku foaming agent. Analisis nilai tambah dilakukan untuk mengetahui gambaran prospek pengembangan produk foaming agent ke depan, sehingga akan memberikan dampak keuntungan bagi pemilik modal, pekerja, dan masyarakat lainnya (Hayami et al., 1987). Nilai tambah (added value) dari natrium laurat dan kalium palmitat minyak sawit adalah pertambahan nilai secara ekonomis dari kedua bahan baku tersebut yang disebabkan oleh penanganan baru melalui proses produksi. Proses produksi tersebut meliputi proses pengolahan, ataupun pengangkutan dan penyimpanan untuk mendapatkan nilai produk menjadi lebih baik (Hayami et al., 1987; Kemenkeu, 2012; Papilo et al., 2020).

Besarnya nilai tambah yang dihasilkan dapat memprediksi apakah asam laurat dan palmitat dari minyak sawit yang dijadikan sebagai bahan baku foaming agent memberikan nilai tambah secara ekonomis atau tidak, dengan diketahuinya nilai tambah diharapkan dapat memberikan gambaran bagi pelaku usaha untuk mengembangkan produk tersebut. Nilai tambah ekonomis produksi foaming agent dari asam lemak minyak sawit diperkirakan cukup menjanjikan, karena selama ini sebagian besar kebutuhan produk foaming agent yang digunakan untuk memadamkan kebakaran lahan gambut di Indonesia merupakan produk impor. Peluang lain adalah diperkirakan beberapa tahun ke depan kebakaran hutan dan lahan gambut masih akan terjadi setiap tahun ketika musim kemarau (Subekti et al., 2017).

Tujuan analisis nilai tambah adalah untuk mengetahui prospek ke depan pengembangan foaming agent lebih lanjut, karena diprediksi kebakaran lahan gambut akan terus berulang setiap tahun pada musim kemarau panjang. Dengan mengetahui nilai tambah bahan baku yang digunakan diharapkan akan menarik pelaku usaha untuk mengembangkan produk foaming agent dari asam lemak minyak sawit, hal tersebut dilakukan karena pemilik modal akan mengembangkan usahanya setelah mengetahui nilai keuntungan yang akan didapatkan (Preckel et al., 2004). Selain itu, analisis nilai tambah berguna sebagai metode untuk memprediksi balas jasa yang diterima pengusaha, potensi peluang lapangan kerja yang diciptakan oleh pelaku usaha dan merangsang pertumbuhan ekonomi baru di lingkungan kawasan lokasi usaha (Hayami et al., 1987; Herdiyandi et al., 2016).

\section{METODE PENELITIAN}

Analisis nilai tambah (value added) dilakukan untuk mengetahui ada atau tidaknya nilai tambah dari penggunaan NL (natrium laurat) dan KP (kalium palmitat) dari asam lemak minyak sawit, sebagai bahan baku utama konsentrat foaming agent untuk aplikasi pada pemadam kebakaran lahan gambut. Sedangkan bahan tambahan untuk meningkatkan kemampuan kinerja foaming agent adalah $\mathrm{NaHCO}_{3}$ (sodium hydrogen carbonate), HG (hexyelene glicol), EDTA (ethylene diamine tetra acetic acid), MgSO4 (magnesium sulfate).

Pada penelitian ini perhitungan nilai tambah dilakukan dengan menggunakan metode Hayami, dengan metode tersebut dapat mengetahui informasi yang lengkap terkait rasio nilai tambah, rasio pendapatan tenaga kerja, rasio keuntungan dan margin keuntungan (Hayami et al., 1987). Perhitungan nilai tambah dengan metode Hayami dilakukan dengan tiga tahapan. Pada tahapan pertama dilakukan analisis bahan baku, kebutuhan bahan baku, jumlah tenaga kerja, faktor konversi, harga produk yang dihasilkan dan upah tenaga kerja. Pada tahapan kedua dilakukan analisis penerimaan dan keuntungan untuk menentukan nilai tambah dan nilai produk. Sedangkan tahapan terakhir adalah analisis balas jasa pemilik faktor produksi untuk menentukan nilai balas jasa pemilik modal dan faktor produksi lainnya. Selain itu, dengan Metode Hayami dapat mempermudah pemilik modal dan pekerja untuk mengetahui perkembangan atau perubahan nilai tambah penggunaan natrium laurat dan kalium palmitat minyak sawit sebagai bahan baku pada produksi foaming agent pemadam kebakaran lahan gambut. 
Perhitungan nilai tambah menggunakan Metode Hayami diperlukan beberapa sumber data, baik data primer maupun data sekunder. Data primer bersumber dari pengembangan hasil penelitian Subekti et al. (2020) dan data sekunder berasal dari harga bahan baku di pasaran serta asumsi penggunaan data pendukung yang relevan. Kebutuhan bahan baku dan asumsi lain disesuaikan dalam rangka untuk mendukung proses produksi foaming agent pemadam kebakaran lahan gambut. Asumsi yang digunakan adalah kebutuhan bahan baku sesuai formula dengan total $1.000 \mathrm{~kg} / \mathrm{hari}$, total harga bahan baku $\mathrm{Rp}$ $15.991,56 / \mathrm{kg}$ dengan rincian dapat dilihat pada Tabel 1.

Asumsi kapasitas produksi $1.000 \mathrm{~kg} / \mathrm{hari}$ dengan harga jual produk yang dihasilkan FAP-MS (foaming agent) Rp 100.000/kg, jumlah tenaga kerja 5 orang, hari orang kerja (HOK) 8 jam/hari (HOK/hari) dan upah tenaga kerja Rp 150.000/HOK. Asumsi penentuan harga jual di antaranya adalah harga bahan baku, biaya produksi dan produk sejenis yang digunakan oleh instansi terkait selami ini dengan harga Rp. 150.000/kg. Asumsi biaya lain dengan nilai Rp 3.137/kg terdiri dari biaya umum sebesar Rp 2.358/kg, biaya utilitas sebesar Rp 156/kg dan biaya penyusutan sebesar Rp 623/kg. Nilai asumsi biaya lain berdasarkan estimasi secara umum dari rencana nilai jual produk yang akan dihasilkan. Selain itu, pemilihan nilai asumsi berdasarkan rencana ke depan untuk pengembangan produksi foaming agent skala industri. Prosedur dan tahapan perhitungan nilai tambah disajikan pada Tabel 2.

Penilaian ada atau tidaknya suatu hasil perhitungan nilai tambah proses produksi berdasarkan kriteria penilaian, jika rasio nilai tambah $>0$ maka hasil produksi memberikan nilai tambah (positif) dan jika rasio nilai tambah $<0$ maka hasil produksi tidak memberikan nilai tambah (negatif) (Novia et al., 2013; Sari et al., 2015). Kategori hasil perhitungan nilai tambah adalah tinggi, sedang dan rendah. Nilai tambah tinggi jika nilai rasio nilai tambah $>40 \%$, nilai tambah rendah jika rasio nilai tambah $<15 \%$ dan nilai tambah dikatakan sedang jika nilai rasio nilai tambah $15-40 \%$ (Kipdiyah et al., 2013).

Tabel 1. Kebutuhan bahan baku pembuatan foaming agent

\begin{tabular}{lcc}
\hline \multicolumn{1}{c}{ Bahan Baku } & Kebutuhan /hari (Kg) & Biaya /Kg (Rp) \\
\hline NL (natrium laurat) & 185,60 & $9.006,05$ \\
KP (kalium palmitat) & 46,30 & 851,40 \\
NaHCO3 (sodium hydrogen carbonate) & 7,20 & 1,584 \\
HG (hexyelene glicol) & 52,70 & 3,162 \\
EDTA (ethylene diamine tetra acetic acid) & 10 & 1,000 \\
MgSO4 (magnesium sulfate) & 2 & 40 \\
Air & 696,20 & 348,10 \\
\hline Total & 1.000 & $15.991,56$ \\
\hline
\end{tabular}

Tabel 2. Kerangka perhitungan nilai tambah metode Hayami

\begin{tabular}{|c|c|c|}
\hline $\mathbf{I}$ & Produk, Bahan Baku dan Harga & \\
\hline (1) & Produk /FAP-MS (kg/hari) & (1) \\
\hline (2) & Bahan baku (kg/hari) & (2) \\
\hline (3) & Tenaga kerja (HKO/hari) & (3) \\
\hline (4) & Faktor konversi & $(4)=(1) /(2)$ \\
\hline (5) & Koefisien tenaga kerja $\mathrm{HKO} / \mathrm{kg}$ ) & $(5)=(3) /(2)$ \\
\hline (6) & Harga FAP-MS (Rp/kg) & (6) \\
\hline (7) & Upah tenaga kerja (Rp/HKO) & (7) \\
\hline II & Penerimaan dan Keuntungan & \\
\hline (8) & Harga bahan baku $(\mathrm{Rp} / \mathrm{kg})$ & (8) \\
\hline (9) & Sumbangan biaya lain $(\mathrm{Rp} / \mathrm{kg})$ & (9) \\
\hline (10) & Nilai produk (Rp/kg) & $(10)=(4) \times(6)$ \\
\hline \multirow[t]{2}{*}{ (11) } & a. Nilai tambah $(\mathrm{Rp} / \mathrm{kg})$ & $(11 a)=(10)-(9)-(8)$ \\
\hline & b. Rasio nilai tambah (\%) & $(11 \mathrm{~b})=(11 \mathrm{a} / 10) \times 100 \%$ \\
\hline \multirow[t]{2}{*}{$(12)$} & a. Pendapatan tenaga kerja $(\mathrm{Rp} / \mathrm{kg})$ & $(12 a)=(5) \times(7)$ \\
\hline & b. Rasio pendapatan tenaga kerja (\%) & $(12 b)=(12 a / 11 a) \times 100 \%$ \\
\hline \multirow[t]{2}{*}{ (13) } & a. Keuntungan $(\mathrm{Rp} / \mathrm{kg})$ & $(13 a)=11 a-12 a$ \\
\hline & b. Rasio keuntungan (\%) & $(13 b)=(13 a / 11 a) \times 100 \%$ \\
\hline III & Balas Jasa Pemilik Faktor Produksi & \\
\hline \multirow[t]{4}{*}{ (14) } & Margin keuntungan (Rp/kg) & $(14)=(10)-(8)$ \\
\hline & a. Pendapatan tenaga kerja $(\%)$ & $(14 \mathrm{a})=(12 \mathrm{a} / 14) \times 100 \%$ \\
\hline & b. Sumbangan biaya lain (\%) & $(14 b)=(9 / 14) \times 100 \%$ \\
\hline & c. Keuntungan pengusaha (\%) & $(14 c)=(13 a / 14) \times 100 \%$ \\
\hline
\end{tabular}




\section{HASIL DAN PEMBAHASAN}

Analisis nilai tambah dilakukan untuk mengetahui rasio nilai tambah dan keuntungan dari penggunaan natrium laurat dan kalium palmitat sebagai bahan baku foaming agent pemadam kebakaran pada lahan gambut, hasil perhitungan nilai tambah disajikan pada Tabel 3.

\section{Analisis Bahan Baku, Produk dan Harga}

Produk yang dihasilkan dari hasil proses formulasi dengan bahan baku utama natrium laurat dan kalium palmitat sesuai asumsi adalah foaming agent dengan kapasitas produksi $1.000 \mathrm{~kg} / \mathrm{hari}$. Bahan baku yang digunakan adalah natrium laurat, kalium palmitat, Bicnat, HG, EDTA, magnesium sulfat dan air dengan total jumlah $1.000 \mathrm{~kg} /$ hari. Proses pembuatan foaming agent membutuhkan tenaga kerja yang diperlukan 5 orang dengan pembagian tugas menjadi tiga, 2 orang karyawan sebagai operator proses sintesis, 2 orang sebagai operator formulasi dan pengemasan serta 1 orang analis merangkap kontrol kualitas. Untuk kegiatan proses produksi dilakukan 7 jam/hari.

Hasil perhitungan nilai tambah pada Tabel 3 faktor konversi sebesar 1, faktor konversi didapatkan dari pembagian nilai output dibagi nilai bahan baku. Nilai konversi tersebut memiliki arti bahwa untuk setiap $1 \mathrm{~kg}$ bahan baku yang digunakan mampu menghasilkan $1 \mathrm{~kg}$ foaming agent, hal ini karena seluruh bahan baku yang diproses menjadi produk. Nilai koefisien tenaga kerja didapatkan dari pembagian jumlah tenaga kerja dengan bahan baku dengan nilai 0,005 , yang artinya bahwa untuk mengolah bahan baku $1.000 \mathrm{~kg}$ dibutuhkan 5 orang karyawan. Asumsi harga produk foaming agent sebesar Rp 100.000/kg, harga penjualan ini ditentukan berdasarkan pertimbangan harga bahan baku, estimasi biaya lainnya dan harga produk foaming agent komersil yang sudah ada di pasaran yang selama ini digunakan sebagai bahan pemadam kebakaran. Upah tenaga kerja sebesar Rp 150.000/hari, nilai tersebut sudah termasuk uang makan dan transportasi. Namun demikian, untuk tunjangan hari raya, biaya kesehatan dan bonus diberikan tergantung peningkatan nilai keuntungan yang dihasilkan. Pemilik usaha memberlakukan upah untuk seluruh karyawan sama karena seluruh karyawan diusahakan untuk saling bekerja sama dalam setiap proses produksi dan mempunyai semangat kekeluargaan yang tinggi. Berdasarkan data-data kegiatan tersebut maka perhitungan nilai tambah dapat dilakukan, karena nilai tambah merupakan nilai yang dihasilkan dari kegiatan suatu unit usaha atau perusahaan dan tenaga kerja, dengan perhitungan nilai penjualan dikurangi biaya-biaya pembelian bahan baku dan jasa lainnya (Staden, 2000).

\section{Analisis Penerimaan dan Keuntungan}

Penentuan harga bahan baku foaming agent ditetapkan berdasarkan harga pasar, dalam penelitian ini asumsi total harga bahan baku adalah $\mathrm{Rp}$ $15.991,56 / \mathrm{kg}$ sesuai harga pada tingkat toko penjual bahan baku (eceran). Sumbangan biaya lain ditetapkan berdasarkan asumsi komponen biaya umum, biaya utilitas dan biaya penyusutan dengan total Rp 3.137,29/kg

Tabel 3. Hasil perhitungan nilai tambah natrium laurat dan kalium palmitat minyak sawit sebagai bahan foaming agent pemadam kebakaran lahan gambut

\begin{tabular}{clr}
\hline I & Produk, Bahan Baku dan Harga & \\
\hline$(1)$ & Produk /FAP-MS (kg/hari) & 1.000 \\
$(2)$ & Bahan baku (kg/hari) & 1.000 \\
$(3)$ & Tenaga kerja (HKO/hari) & 5 \\
$(4)$ & Faktor konversi & 1 \\
$(5)$ & Koefisien tenaga kerja HKO/kg) & 0,005 \\
$(6)$ & Harga FAP-MS (Rp/kg) & 100.000 \\
$(7)$ & Upah tenaga kerja (Rp/HKO) & 150.000 \\
\hline II & Penerimaan dan Keuntungan & $15.991,56$ \\
\hline$(8)$ & Harga bahan baku (Rp/kg) & $3.137,29$ \\
$(9)$ & Sumbangan biaya lain (Rp/kg) & 100.000 \\
$(10)$ & Nilai produk (Rp/kg) & $80.871,15$ \\
$(11)$ & Nilai tambah (Rp/kg) & 80,87 \\
& Rasio nilai tambah (\%) & 750,00 \\
$(12)$ & Pendapatan tenaga kerja (Rp/kg) & 0,93 \\
& Rasio pendapatan tenaga kerja (\%) & $80.121,15$ \\
$(13)$ & Keuntungan (Rp/kg) & 99,07 \\
\hline & Rasio Keuntungan (\%) & \\
\hline III & Balas Jasa Pemilik Faktor Produksi & $84.008,44$ \\
\hline$(14)$ & Margin keuntungan (Rp/kg) & 0,89 \\
& a. Pendapatan tenaga kerja (\%) & 3,73 \\
& b. Sumbangan biaya lain (\%) & 95,37 \\
\hline
\end{tabular}


Nilai produk ditentukan dari perkalian harga bahan jual produk dengan faktor konversi, yaitu sebesar Rp 100.000, artinya bahwa setiap $1 \mathrm{~kg}$ foaming agent harga jualnya adalah $\mathrm{Rp} 100.000 / \mathrm{kg}$.

Nilai tersebut merupakan nilai penerimaan kotor dari unit usaha. Nilai tambah dihitung dari pengurangan nilai produk dengan harga bahan baku dan biaya yang lain. Hasil perhitungan nilai tambah berkontribusi dalam penentuan nilai produk, rasio nilai tambah yang dihasilkan sebesar $80,87 \%$, rasio nilai tambah didapat dari rasio antara nilai tambah dengan nilai produk. Besaran rasio nilai tambah tersebut memberikan arti bahwa setiap nilai output $\mathrm{Rp} 80.871,15 / \mathrm{kg}$, terdapat $80,87 \%$ nilai tambah dari produk foaming agent yang dihasilkan. Kriteria positif dihasilkan karena rasio nilai tambah $80,87 \%>0$, artinya bahwa proses produksi foaming agent menggunakan bahan baku utama natrium laurat dan kalium palmitat memberikan nilai tambah bagi pemilik usaha. Sedangkan dari nilai kategori, dengan rasio nilai tambah sebesar 80,87\% > $40 \%$ termasuk dalam nilai kategori tinggi. Nilai kategori tinggi artinya bahwa proses produksi foaming agent menggunakan bahan baku utama natrium laurat dan kalium palmitat memberikan nilai tambah keuntungan yang tinggi bagi pelaku usaha, hal tersebut karena nilai kategori yang dihasilkan di atas $40 \%$ (Kipdiyah et al., 2013).

Pendapatan tenaga kerja langsung dihitung dari perkalian koefisien tenaga kerja dengan pendapatan setiap tenaga kerja, nilai pendapatan tenaga kerja sebesar Rp 750/kg. Nilai tersebut merupakan pendapatan setiap tenaga kerja yang diperoleh dari setiap kilogram bahan baku foaming agent yang diolah. Perimbangan antara pendapatan unit usaha dengan pendapatan tenaga kerja adalah $0,93 \%$, artinya bahwa pendapatan tenaga kerja diambil dari nilai pendapatan pemilik usaha sebesar $0,93 \%$. Nilai keuntungan dihitung dari hasil pengurangan nilai tambah dikurangi pendapatan tenaga kerja, dari hasil perhitungan nilai keuntungan untuk setiap $1 \mathrm{~kg}$ foaming agent yang dijual dengan harga $\mathrm{Rp} 100.000 / \mathrm{kg}$ pengusaha mendapatkan keuntungan bersih sebesar Rp 80.121,15. Nilai keuntungan tersebut termasuk ke dalam tingkat keuntungan tinggi karena rasio keuntungan yang diperoleh pemilik usaha sebesar 99,07\%. Berdasarkan nilai rasio keuntungan tersebut, usaha proses pembuatan foaming agent dari bahan baku utama natrium laurat dan kalium palmitat selain memberikan keuntungan untuk pelaku usaha juga akan memberikan dampak dalam meningkatkan pertumbuhan ekonomi baru di lokasi usaha. Pertumbuhan ekonomi baru di lokasi tempat usaha merupakan dampak positif dari kegiatan usaha yang akan dilakukan, hal tersebut merupakan kontribusi keberadaan usaha produksi foaming agent dengan memanfaatkan bahan baku lokal. Dampak lain dari usaha tersebut adalah meningkatnya jumlah produk turunan dari minyak sawit, dimana peningkatan tersebut merupakan salah satu pengembangan hilirisasi kelapa sawit di Indonesia. Dengan pengembangan hilirisasi kelapa sawit, diharapkan akan memberikan dampak pada stabilitas harga buah kelapa sawit di tingkat hulu dan peningkatan penggunaan minyak sawit untuk produk non pangan di tingkat hilir. Selain itu, usaha tersebut juga akan memberikan kontribusi dalam memberikan penghasilan bagi seluruh tenaga kerja dan berperan dalam penyediaan lapangan kerja (Hasanah et al., 2015).

\section{Analisis Balas Jasa Pemilik Faktor Produksi}

Analisis balas jasa meliputi margin keuntungan yang dihitung dari pengurangan nilai produk dengan nilai harga bahan baku, dimana nilai margin keuntungan adalah $\mathrm{Rp} 84.008,44 / \mathrm{kg}$. Nilai margin tersebut merupakan kontribusi dari nilai pendapatan tenaga kerja sebesar $0,89 \%$, sumbangan biaya lain sebesar 3,73\% dan keuntungan dari pengusaha selaku pemilik modal sebesar $95,37 \%$ yang merupakan kontribusi terbesar dalam memberikan margin keuntungan. Berdasarkan sebaran kontribusi nilai tersebut terlihat bahwa balas jasa terbesar yang diperoleh perusahaan adalah dari keuntungan pemilik usaha sebagai pemilik modal, urutan kedua penyumbang balas jasa adalah sumbangan biaya lain dan ketiga adalah pendapatan tenaga kerja. Nilai tambah ditentukan oleh besarnya komponen nilai produk, harga bahan baku dan sumbangan biaya yang lain, sedangkan untuk menentukan apakah unit usaha tersebut padat modal atau padat karya dilihat dari proporsi tenaga kerja dan nilai keuntungan terhadap nilai tambah (Hayami et al., 1987).

Penjelasan di atas terlihat bahwa usaha produksi foaming agent secara umum merupakan padat modal. Hal tersebut dilihat dari proporsi rasio tenaga kerja menyumbang $0,93 \%$ terhadap penerimaan dan keuntungan, sedangkan sisanya rasio keuntungan merupakan kontribusi pemilik modal. Hal tersebut merupakan salah satu keunggulan usaha produksi foaming agent yang sudah memanfaatkan teknologi proses yang cukup baik dengan menghasilkan keuntungan yang tinggi. Meskipun di lain sisi penggunaan sumber daya manusia yang sedikit dan dibutuhkan kemampuan tenaga kerja untuk menguasai teknologi proses yang baik, tetapi produktifitas usaha yang cukup baik yang akan menunjang kelancaran usaha yang dilakukan. Dengan nilai keuntungan tersebut, memberikan kepastian pelaku usaha dalam menjalankan aktivitas usahanya. Namun demikian pelaku usaha juga perlu memberikan perhatian dari aspek sosial di tempat akan dibangunnya lokasi usaha. Selain faktor sosial, perhatian lain adalah faktor lingkungan yang perlu dikaji berdasarkan regulasi yang ada. Hal tersebut dilakukan sebagai usaha untuk meminimalisasi kerugian dalam berusaha. Nilai keuntungan yang tinggi merupakan harapan setiap pelaku usaha, dengan mengendalikan setiap biaya yang digunakan sehingga akan meningkatkan nilai tambah (Hidayat et al., 2012). 


\section{KESIMPULAN DAN SARAN}

\section{Kesimpulan}

Analisis nilai tambah menggunakan Metode Hayami telah dilakukan, dari hasil analisis dihasilkan bahwa prospek pengembangan foaming agent untuk aplikasi pemadam kebakaran lahan gambut berbahan baku natrium laurat dan kalium palmitat minyak sawit berpeluang untuk dikembangkan. Dari perhitungan diperoleh hasil bahwa nilai tambah dari foaming agent berbahan baku baku natrium laurat dan kalium palmitat minyak sawit adalah sebesar Rp 80.871,15 per kilogram input, atau sebesar $80,87 \%$, sehingga berada pada kategori nilai tambah yang tinggi. Selain itu, usaha tersebut juga akan memberikan keuntungan dengan kategori tinggi, karena rasio keuntungan yang diperoleh pemilik usaha sebesar $99,07 \%$.

\section{Saran}

Untuk penelitian lanjutan dapat dilakukan dengan menghitung kelayakan finansial yang meliputi NPV (Net Present Value), IRR (Internal Rate of Return), dan Net B/C Rasio (Net Benefit Cost Ratio), PBP (Payback Period) dan BEP (Break Event Point) sebagai sumber data primer dari biaya lain. Selain itu perlu dilakukan pengembangan proses formulasi menggunakan bahan-bahan lain dalam rangka untuk meningkatkan kinerja pemadaman foaming agent.

\section{UCAPAN TERIMAKASIH}

Penulis mengucapkan terimakasih kepada Ibu Dr. Mira Rivai dan rekan-rekan di SBRC atas bantuan tenaga, bahan, peralatan, dan ilmunya yang sangat bermanfaat serta kesempatan untuk melakukan penelitian.

\section{DAFTAR PUSTAKA}

Hasanah U, Masyhuri, dan Djuwari. 2015. Analisis nilai tambah agroindustri sale pisang di kabupaten Kebumen. Jurnal Ilmu Pertanian. 18(3): 141-149.

Hayami Y, Kawagoe T, Morooka Y, Siregar M. 1987. Agricultural Marketing and Processing in Upland Java. A Perspective from a Sunda Village. Bogor (ID): CPGRT Cent.

Herdiyandi, Rusman Y, dan Yusuf MN. 2016. Analisis nilai tambah agroindustri tepung tapioka di desa neratengah kecamatan cineam kabupaten Tasikmalaya. Jurnal Ilmu Mhs Agroinfo Galuh. 2(2): 81-86.

Hidayat S, Marimin, Suryani A, Sukardi, Yani M. 2012. Modifikasi metode hayami untuk perhitungan nilai tambah pada rantai pasok agroindustri kelapa sawit. Jurnal Teknologi Industri Pertanian. 22(1): 22-31.

[Kemenkeu] Kementrian Keuangan Republik Indonesia. 2012. Kajian nilai tambah produk pertanian. Pusat Kebijakan Ekonomi Makro. Badan Kebijakan Fiskal. Jakarta (ID). Kemenkeu.

Kipdiyah S, Hubeis M, dan Suharjo B. 2013. Strategi rantai pasok sayuran organik berbasis petani di Kecamatan Pangalengan, Kabupaten Bandung. Manajamemen IKM. 8(2): 99-114.

Mizuki H, Uezu K, Kawano T, Kadono T, Kobayashi M, Hatae S, Oba Y, Iwamoto S, Mitumune S, Nagatomo Y, Owari M, Umeki H, Yamaga K. 2007. Novel environment friendly soap-based fire-fighting agent. Journal Environ Eng Manage. 17(6): 403408.

Novia W, Zakaria WA, dan Lestari DAH. 2013. Analisis Nilai Tambah dan Kelayakan Pengembangan Agroindustri Beras Siger. JIIA. 1(3): 210-217.

Papilo P, Prasetiyo D, Hartati M, Permata EG, Rinaldi A. 2020. Analisis dan penentuan strategi perbaikan nilai tambah pada rantai pasok kelapa sawit (Studi Kasus Provinsi Riau). Jurnal Teknologi Industri Pertanian. 30(1): 13-21.

Preckel PV, Gray A, Boehlje M, Kim S. 2004. Risk and Value Chains: Participant Sharing of Risk and Rewards. Journal Chain and Network Service. 4(1): 25-32.

Rivai M, Hambali E, Suryani A, Fitria R, Firmansyah S, Pradesi J. 2017. Synthesis of Palm Oil Fatty Acid as Foaming Agent for Firefighting Application. Conf. Ser.: Earth Environ. Sci. 2016 Okt. 10-11; Bogor, Indonesia. Bogor (ID): IOP 65: 012047. doi:10.1088/1755-1315/65/1/012047.

Sari IRM, Zakaria WA, dan Affandi MI. 2015. Kinerja Produksi dan Nilai Tambah agroindustri emping melinjo di kota Bandar Lampung. Jurnal Ilmu-Ilmu Agribisnis. 3(1): 18-25.

Staden CJV. 2000. The value-added statement: bastian of social reporting or dinosaur of financial reporting college of business. Massey Discussion Paper No. 200, Available SSRN: http://dx.doi.org/10.2139/ssrn.61130 $\underline{2}$

Subekti P, Hambali E, Suryani A, Suryadarma P. 2017. potential production of palm oil based foaming agent as fire extinguisher of peatlands in indonesia: literature review. Earth Environ. Science. 10-11; Bogor, Indonesia. Bogor (ID): IOP. 65: 012038. doi:10.1088/1755-1315/65/1/012038.

Subekti P, Hambali E, Suryani A, Suryadarma P, Saharjo BH, Rivai M. 2018. Selection of Peat Firefighting Foam from Palm Oil Fatty Acid Saponification with Simple Additive Weighting (SAW) Method. SNTM- 
BKSTM. 2018 Okt.03-05; Kupang, Indonesia. Kupang (ID). Dep. Teknik Mesin, Undana: 068-071.

Subekti P, Hambali E, Suryani A, Suryadarma P, Saharjo BH, Rivai M. 2019. The formulation of foaming agents from palm oil fatty acid and performance test on peat fires. Journal Japan Institute Energy. 98 (5): 95-100.

Subekti P, Hambali E, Suryani A, Suryadarma P, Saharjo BH, Rivai M. 2020. The effects of magnesium sulphate addition into foaming agents resulted from palm oil fatty acid saponification in the performance of peat fire suppression. Conf. Ser.: Earth Environ. Sci. 2019 August. 19-20; Bogor, Indonesia. Bogor (ID): $\quad$ IOP 460: 012028. doi:10.1088/1755-1315/460/1/012028. 